\title{
ARTICLES
}

Submitted 11.13.2018. Approved 06.27.2019

Evaluated through a double-blind review process. Scientific Editor: Eduardo Davel

Original version

DOI: http://dx.doi.org/10.1590/So034-759020190502

\section{HUMOR AS CATALYST AND NEUTRALIZER OF LEADERSHIP EFFECTIVENESS}

\author{
Humor como catalisador e neutralizador da eficácia da liderança \\ Humor como catalizador y neutralizador de la eficacia del liderazgo
}

\begin{abstract}
This study examines the effects of (in)consistent leadership behaviors in promoting (or suppressing) relevant work outcomes for temporary employees such as interns. Specifically, to better understand the drivers of internship effectiveness, we hypothesized that supervisor humor interacts with leadership style, sending implicit messages about the organizational and supervisory relationship, thus shaping interns' attitudes and behaviors. Using a sample of 164 interns, we empirically examined the moderating effect of humor (affiliative and aggressive) on the relationship between leadership styles (transformational and laissez-faire), attitudes (satisfaction and stress), and behaviors (negligence and job acceptance intentions) using a two-wave research design. Our findings were consistent with the hypotheses, suggesting that humor needs to be tailored to leadership styles to predict interns' attitudinal and behavioral responses, with different types of humor interacting differently across leadership styles. Implications for further research are discussed.
\end{abstract}

KEYWORDS | Leadership styles, humor, inconsistency, ambivalence, internship.

\section{RESUMO}

\section{FILIPE SOBRAL}

filipe.sobral@fgv.br

ORCID: 0000-0002-9900-9464

\section{LILIANE FURTADO²}

lilianempf@gmail.com

ORCID: 0000-0003-3510-8321

\section{GAZI ISLAM ${ }^{3}$}

gazi.islam@grenoble-em.com ORCID: 0000-0002-6503-6018

${ }^{1}$ Fundação Getulio Vargas, Escola Brasileira de Administração Pública e de Empresas, Rio de Janeiro, RJ, Brazil

\section{Universidade Federal} Fluminense, Programa de PósGraduação em Administração/ Mestrado, Rio de Janeiro, RJ, Brazil

${ }^{3}$ Grenoble Ecole de Management, Department People, Organizations and Society, Grenoble, France
Este estudo examina os efeitos da (in)consistência de comportamentos de liderança na promoção (ou supressão) de resultados do trabalho de trabalhadores temporários, como é o caso de estagiários. Especificamente, para melhor entender os impulsionadores da eficácia dos estágios, avaliamos em que medida o humor do supervisor interage com o seu estilo de liderança, por meio de mensagens implícitas sobre os códigos e relacionamentos organizacionais, moldando, assim, as atitudes e os comportamentos dos estagiários. Usando uma amostra de 164 estagiários, com dados coletados em duas ondas, examinamos empiricamente o efeito moderador do humor (afiliativo e agressivo) na relação entre estilos de liderança (transformacional e laissez-faire), atitudes (satisfação e estresse) e comportamentos (negligência e intenções de permanência). Os resultados foram consistentes com as hipóteses de pesquisa, sugerindo que o humor precisa ser consistente com os estilos de liderança para promover as respostas atitudinais e comportamentais adequadas, com diferentes tipos de humor interagindo de maneira diferente com os estilos de liderança. Implicações para futuras pesquisas são discutidas.

PALAVRAS-CHAVE I Estilos de liderança, humor, inconsistência, ambivalência, estágios.

\section{RESUMEN}

Este estudio examina los efectos de la (in)consistencia de comportamientos de liderazgo en la promoción (o supresión) de los resultados laborales de trabajadores temporales, como en el caso de los pasantes. En concreto, para entender mejor los impulsores de la eficacia de las pasantías, evaluamos en qué medida el humor del supervisor interactúa con su estilo de liderazgo, por medio de mensajes implícitos sobre los códigos y relaciones organizacionales, moldeando, así, la actitud y el comportamiento de los pasantes. Con una muestra de 164 pasantes, con datos recogidos en dos etapas, examinamos empíricamente el efecto moderador del humor (afiliativo y agresivo) en la relación entre estilos de liderazgo (transformacional y laissez-faire), actitudes (satisfacción y estrés) y comportamientos (negligencia e intenciones de permanencia). Los resultados fueron consistentes con las hipótesis de investigación y sugieren que el humor debe ser consistente con los estilos de liderazgo para promover las respuestas actitudinales y conductuales adecuadas, con diferentes tipos de humor que interactúen de manera diferente con los estilos de liderazgo. Asimismo, se discuten las implicaciones para futuras investigaciones. PALABRAS CLAVE I Estilos de liderazgo, humor, inconsecuencia, ambivalencia, pasantías. 


\section{INTRODUCTION}

Organizations face a challenging business environment, marked by diversity, complexity, and constant disruptions (Siggelkow \& Rivkin, 2005). In this context, leaders must make decisions knowing that uncertainty and ambiguity are the new normal. Humor has been considered a good remedy to cope with contradictions and tensions inherent to modern organizations, as it helps leaders manage business idiosyncrasies and ambiguities more positively (Hatch, 1997; Huang \& Kuo, 2011). Indeed, a growing body of literature emphasizes the prominence of humor as a leadership tool in organizational settings (e.g., Avolio, Howell, \& Sosik 1999; Robert \& Wilbanks, 2012). Studies highlight the positive effects of humor on conducting interpersonal and group processes (e.g., Cooper, Kong, \& Crossley, 2018; Robert, Dunne, \& Iun, 2016; Robert \& Wilbanks, 2012; Romero \& Pescosolido, 2008), coping with emotional tension and stress (Arendt, 2009; Hughes, 2009; Lynch, 2009; Romero \& Cruthirds, 2006), and mitigating the hierarchal power structure in organizations (George, 2013).

However, research shows that, sometimes, leaders' use of humor is inconsistent with their leadership style, that is, their adopted behavioral patterns to influence and motivate followers' behavior (Tremblay \& Gibson, 2016; Vecchio, Justin, \& Pearce, 2009). Such inconsistencies have important consequences on followers' attitudes and behaviors, since they expect leaders to act predictably and consistently (De Cremer, 2003; Mullen, Kelloway, \& Teed, 2011). Thus, both leadership styles and humor are key to establishing supervisor-subordinate bonds in the workplace (Pundt \& Herrmann, 2015), and when inconsistent with each other, they can trigger vexing mixed feelings and thoughts among followers that characterize ambivalence (Ashforth, Rogers, Pratt, \& Pradies, 2014; Methot, Melwani, \& Rothman, 2017).

Such ambivalent feelings are especially stronger for nonregular and precarious employees, such as interns. Interns are different from regular employees: they possess less selfefficacy and autonomy due to limited work experience (Wendlandt $\&$ Rochlen, 2008) and have ambiguous and often precarious career status (Rose, 2017). Consequently, interns are particularly susceptible to immediate supervisors directly responsible for introducing, accompanying, and guiding them throughout the internship period (Beenen, 2014; Kenny et al., 2015; Liu, Ferris, Xu, Weitz, \& Perrewé, 2014; McHugh, 2017; Rose, Teo, \& Connell, 2014). Research shows that leadership behaviors are instrumental in helping interns make sense of their new reality (D'Abate, Youndt, \& Wenzel, 2009; Zhao \& Liden, 2011) and clarify role expectations (Liu, Xu, \& Weitz, 2011). In ambivalent situations, interns feel pulled in opposite directions, causing discomfort, disorientation, and apprehension. By impeding interns from making sense of the appropriate norms and building clear expectations, ambivalence may affect their propensity to commit to or disengage from the organization (Ashforth et al., 2014; Methot et al., 2017). However, we know little about how young, inexperienced, and precarious workers, such as interns, react to ambivalence triggered by leaders' inconsistent behaviors. Particularly, to our knowledge, empirical studies connecting these streams of research are rare in the Brazilian work context.

This study addresses this gap by exploring the combined effects of (in)consistent supervisors' leadership and humor styles on interns' experiences during the internship period. Through the ambivalence perspective (Ashforth et al., 2014), we argue that inconsistent leadership and humor styles elicit ambivalent feelings in interns about their work experiences, which motivates them to take action to reduce the resultant discomfort. Specifically, we test the interplay between humor styles (affiliative and aggressive) and leadership styles (transformational and laissezfaire) on interns' attitudes (satisfaction and stress) and behaviors (job acceptance intention and negligence). Overall, this study attempts to demonstrate that inconsistent signals from leaders undermine internship outcomes as they foster undesirable feelings and ambivalent experiences by interns.

\section{LEADERSHIP AND THE USE OF HUMOR}

Due to humor's relational and informational roles in interpersonal communication (Cooper et al., 2018; Pundt \& Herrmann, 2015), humor is considered a crucial tool to help managers achieve their objectives (Cooper, 2008; Pundt, 2015; Tremblay \& Gibson, 2016). In a recent empirical study with Brazilian executives, optimism and sense of humor were found to be two of the most relevant managerial competences of modern leaders (Sant'Anna, Campos, \& Lótfi, 2012). Leaders seek humor, both contrived and spontaneous, to make sense of incongruities that inevitably exist in business settings (Hatch, 1997; Huang \& Kuo, 2011). Further, humor is considered especially useful during organizational entry, when ideas, values, and tasks are shared massively and relationships are formed (Heiss \& Carmack, 2012; Lynch, 2002; Sobral \& Islam, 2015). Given humor's ability to stimulate rapid affective bonds (Robert \& Wilbanks, 2012), leaders' use of humor may be particularly effective at early stages of employment or traineeship, condensing drawn-out relational processes between leaders and followers into rich momentary exchanges.

We define humor as a multifaceted construct reflecting a behavioral condition (i.e., expression of humor vs. a "sense" of 
humor) involving an intention to be amusing, either by verbal (jokes and witticisms) or non-verbal (visual and gestural) means (Cooper, 2005). Humor is thus fundamentally interpersonal, although not necessarily positive. Martin et al. (2003) distinguish four humor styles according to content (positive vs. negative) and target focus (self vs. others). Positive styles include affiliative and self-enhancing humor, while negative styles include aggressive and self-defeating humor. Since our study is interested mainly in the effects of leaders' humor directed toward interns, we focus only on other-directed humor, namely, affiliative and aggressive humor. Affiliative humor is a friendly type humor to build and enhance interpersonal relationships through funny stories, jokes, and witty comments, while aggressive humor involves irony, sarcasm, ridicule, and other demeaning humor toward others, representing the dark side of humor (Martin et al., 2003).

Among the different techniques available to leaders, affiliative humor allows establishment of interpersonal, affectladen relationships with followers (Cooper, 2008; Hughes, 2009; Pundt \& Herrmann, 2015; Robert et al., 2016) as well as communication of work-related information and expectations (Romero \& Pescosolido, 2008). Affiliative humor helps promote interpersonal intimacy (Duncan, Smeltzer, \& Leap, 1990) and reduce the salience of hierarchy (Romero \& Cruthirds, 2006), thus fostering high-quality leader-follower relationships (Cooper, 2008; Pundt \& Venz, 2017). The positive atmosphere promoted by humor may help explain its effects on creativity (Arendt, 2009), group productivity (Clouse \& Spurgeon, 1995), and unit-level effectiveness (Avolio et al., 1999).

In addition, affiliative humor provides important information that may be unstated in formal rules or difficult to express directly (Adelswärd \& Oberg, 1998). Some information may be difficult or tacit but can be disseminated imperceptibly and effectively through humor (Gruner, 1999), leading to, among other things, increased acceptance of leader messages (Greatbatch \& Clark, 2003; Zepeda, Franco, \& Preciado, 2014). This informational function of humor is critical for newcomers, as they use humor to interpret and assimilate job expectations and organizational culture and develop new affiliations (Heiss \& Carmack, 2012).

In contrast to affiliative humor, aggressive humor is maladaptive, hurtful to others, and counterproductive for building and maintaining high-quality leader-follower exchange relationships (Pundt \& Herrmann, 2015). This is because it increases perceived social distance between leaders and followers (Kim, Lee, \& Wong, 2016). While affiliative humor sends positive messages about an organization, aggressive humor can be used to sabotage or undermine organizational objectives (Fleming \&
Spicer, 2002). Such humor, far from signaling a safe atmosphere, acts to vent dissatisfaction (Sturdy \& Fineman, 2001), sending the opposite message to newcomers and increasing organizational anxiety and stress (Huo, Lam \& Chen, 2012). Aggressive humor can also hurt unintentionally, as what supervisors find "funny" may be unintentionally hurtful. This indirectness differentiates negative humor from related yet distinct concepts such as abusive supervision (Tepper, 2000).

\section{INCONSISTENT LEADERS AND AMBIVALENT INTERNS}

Humor can be an important tool for leadership; however, research shows that sometimes using humor can be inconsistent with the leadership style, that is, the leaders' set of behaviors to provide direction and motivate followers (Avolio et al., 1999; Tremblay \& Gibson, 2016). For example, a supervisor may display absent leadership style (laissez-faire), while adopting affiliative humorous communication. Conversely, a supervisor can adopt a more transformational relationship with interns but use an aggressive (and dark) form of humor. The polarized nature of leadership and humor styles, roughly categorized as constructive or offensive, makes inconsistencies between these behaviors more salient (Tremblay \& Gibson, 2016; Vecchio et al., 2009).

Leaders' inconsistency is found to be harmful to both followers and organizations (Tremblay \& Gibson, 2016). However, while desirable, consistency is somewhat challenging for leaders constantly confronted by multifaceted goals and required to balance contradictory demands and play multiple roles (Rothman et al., 2017).

When manifested by leaders, inconsistent behaviors are sources of subordinates' vexing mixed feelings that characterize ambivalence (Ashforth et al., 2014). Ambivalence refers to holding opposing affective/cognitive orientations toward another, such as loving and hating the same person, simultaneously. The experience of ambivalence tends to be aversive and dysfunctional (Ashforth et al., 2014; Methot et al., 2017), even if non-conscious, driving responses aimed at warding off these undesirable feelings.

The (in)consistency of leaders' behaviors is particularly important for predictions regarding leadership effectiveness, as ambivalence experienced by interns likely triggers attitudinal and behavioral reactions. That is, humor buffers or amplifies the effects of leadership styles, and these moderating effects differ according to the form of humor (Robert \& Wilbanks, 2012). Similar to the literature noting positive-negative differences in affect- 
related phenomena (Watson, Clark \& Tellegen, 1984), affiliative humor should act primarily on positive attitudes, while aggressive humor should be associated with strain-related and negative attitudes. Specifically, we hypothesize that affiliative humor works mainly by interacting with leadership styles to augment positive intern attitudes (i.e., internship satisfaction), while offensive and aggressive humor interacts with leadership styles to increase anxiety-related negative attitudes (i.e., stress).

\section{HYPOTHESES DEVELOPMENT}

\section{Transformational leadership and humor}

Transformational leaders act as mentors and role models for employees, encouraging subordinates to transcend individual aspirations for the organization (Judge \& Piccolo, 2004). Transformational leadership helps interns experience lower stress and increased satisfaction (Baranik, Roling \& Eby, 2010; D’Abate et al., 2009), making them more likely to continue working for the organization after the internship ends (Beenen \& Rousseau, 2010).

Affiliative humor should be consistent and aligned with transformational leadership, because transformational leaders develop affective bonds with followers (see Ng, 2017, for a meta-analysis). Using affiliative humor, supervisors consistently reinforce positive bonds and identification that help establish transformational relationships (Pundt \& Herrmann, 2015; Terrion \& Ashforth, 2002). Moreover, by creating a positive working environment, affiliative humor facilitates supervisor-intern interactions (Kim et al., 2016), making transformational behaviors even more impactful. Thus, being a constructive form of exerting leadership, affiliative humor should augment the effects of transformational leadership on internship outcomes.

Conversely, aggressive humor may undo the effects of transformational leadership. While transformational supervisors foster emotional dependence and trust in interns (Kark, Shamir, \& Chen, 2003), mocking or aggressive humor undermines trust and positive relationships. Such inconsistent behaviors create uncertainty regarding supervisors' intentions and trustworthiness (Tremblay \& Gibson, 2016). Accordingly, a mixture of constructive leadership and offensive humor inculcates in interns a sense of being simultaneously attracted to and repulsed by supervisors, thus fostering ambivalent feelings toward them (Ashforth et al., 2014). This ambivalent condition is stressful and aversive for employees (Uchino et al., 2012); it is more likely to affect vulnerable groups such as interns, thus leading to negative outcomes.
H1a. Consistency between transformational leadership and affiliative humor augments transformational leaders' positive effects on satisfaction, leading to more positive outcomes (lower neglect and higher job acceptance intentions).

$\mathrm{H}_{1}$ b. Inconsistency between transformational leadership and aggressive humor neutralizes transformational leaders' stress reduction effects, leading to more negative outcomes (greater neglect and lower job acceptance intentions).

\section{Laissez-faire leadership and humor}

While transformational leaders provide a vision for followers, laissez-faire leadership can be a detached leadership style where leaders evade responsibilities, fail to assist followers, and hesitate to take positions on important issues (Bass, 1985). Laissez-faire behaviors are likely to be detrimental to intern learning, causing stress (Vullinghs, De Hoogh, Den Hartog, \& Boon, 2018), dissatisfaction, and negative responses toward their jobs (Beenen \& Rousseau, 2010; Liu et al., 2011; Sosik \& Godshalk, 2000). These effects are driven by a lack of direction under laissezfaire leaders, which fails to fulfill interns' psychosocial needs and undermines trust (Sosik \& Godshalk, 2000).

Affiliative humor by a laissez-faire supervisor reflects inconsistency, since positive affective signals in the negative leadership relationship context seem contradictory and conflicting (Tremblay \& Gibson, 2016). Therefore, by mixing an unsupportive leadership style with affiliative humor, supervisors contribute to emergence of interns' ambivalent feelings and, consequently, reduction of satisfaction.

However, use of aggressive humor by laissez-faire supervisors is likely to be seen as consistent and predictable by interns (Uchino et al., 2012). Both the laissez-faire style and aggressive humor indicate disinterest in subordinates (Cooper, 2008) and likely reinforce each other's effects on the supervisorintern relationship. That is, aggressive humor likely diminishes the leaders' credibility further. In this scenario, such humor may be especially bad, promoting decidedly negative attitudes in interns and affecting their subsequent commitment to the organization.

H2a. Inconsistency between laissez-faire leadership and affiliative humor reinforces laissez-faire leaders' negative effects on satisfaction, leading to more negative outcomes (greater neglect and lower job acceptance intentions).

$\mathrm{H} 2 \mathrm{~b}$. Consistency between laissez-faire leadership and aggressive humor reinforces laissez-faire leaders' stress generation effects, leading to more negative outcomes (greater neglect and lower job acceptance intentions). 


\section{METHODS}

\section{Sample and procedure}

Participants were recruited from career centers and internship programs of a major Brazilian private university in Rio de Janeiro, Brazil. Brazil has the advantage of an extensive history of internships in higher education, typically involving students on sponsored projects during their final years before graduation. In Brazil, internships are regulated federally by the Internship Act (Law no. 11.788, September 25, 2008) and require formal academic oversight.

The study was designed as a two-wave survey with a twoweek time lag. Invitations containing a cover letter explaining the research purpose, instructions, and link to the survey were sent through email. In the first wave ( $\left.T_{1}\right)$, participants rated their supervisors on leadership style and humor use. In the second wave ( $\left.T_{2}\right)$, participants rated both mediators (satisfaction and stress) and dependent variables (job acceptance intentions and negligent behaviors). As an incentive, students were offered lottery tickets for a prize distributed subsequently. However, these were not forfeited if participants desisted from the study, and the study's voluntary and anonymous nature was emphasized to encourage candid responses and reduce social desirability bias.

In all, 164 interns completed both questionnaire waves. Students were on average 22 years old; $55 \%$ were female, $73 \%$ were in their final year of graduation, and most were business majors (42\%). Approximately $54 \%$ of participants had male supervisors during the internship.

\section{Measures}

\section{Leadership style}

Supervisor leadership style was measured using the Multifactor Leadership Questionnaire Form 5X (MLQ-5X) (Bass \& Avolio, 1990). We selected four items to represent transformational leadership subscales' core dimensions: idealized influence or charisma ("my direct supervisor talks optimistically about the future"), inspirational leadership ("my direct supervisor provides a vision of what lies ahead"), intellectual stimulation (“my direct supervisor provides reasons to change my way of thinking about problems"), and individualized consideration ("my direct supervisor spends time teaching and coaching me"). Laissez-faire leadership was assessed by four items (e.g., "my direct supervisor is likely to be absent when I need him/her"). Interns rated how frequently their supervisor engaged in each behavior on a five-point scale, ranging from 1 (not at all) to 5 (frequently, if not always). The reliability of these two leadership scales was 0.81 and 0.72 , respectively.
Humor

Supervisors' humor was measured using subscales for affiliative and aggressive humor from the Humor Styles Questionnaire (Martin et al., 2003). Respondents rated the frequency of a set of leader's behaviors on a five-point scale, ranging from 1 (never or very seldom) to 5 (very often). A sample item for the affiliative humor scale is, "My supervisor enjoys making people laugh," while that for aggressive humor scale is "If someone makes a mistake, my supervisor will often tease them about it." The affiliative and aggressive humor scales' reliability was 0.83 and 0.91 , respectively.

\section{Internship satisfaction}

Intern satisfaction was measured with a six-item scale derived from Brayfield and Rothe's (1951) Job Satisfaction Index using a five-point Likert-type scale, ranging from 1 (strongly disagree) to 5 (strongly agree). Some examples of the items are "I feel fairly satisfied with my internship" and "I feel that I am happier with my internship than most people." The scale's reliability was 0.89 .

\section{Job stress}

Intern stress was assessed with a five-item scale adapted from Ivancevich and Matteson's (1980) Stress Diagnostic Survey using a five-point Likert-type scale, ranging from 1 (strongly disagree) to 5 (strongly agree). We selected items to represent the scale's core dimensions: role ambiguity, role conflict, quantitative and qualitative role overload, and career development concerns. Some examples of the items are "My job duties and work objectives are unclear to me" and "I work on unnecessary tasks and projects." The scale's reliability was 0.85 .

\section{Job acceptance intentions and negligent behavior}

Intention to be permanently hired by the host company and negligent behaviors were both measured with three-item scales adapted from Leck and Saunders (1992). Participants were asked to indicate on a five-point scale, ranging from 1 (strongly disagree) to 5 (strongly agree), how strongly they agree with various behaviors at work. Examples of items included are “I wish to be formally employed by this organization after finishing my internship" and "I put in less effort in my work than I know I can." The job acceptance intention and negligent behavior scales' reliability was 0.86 and 0.73 , respectively. 


\section{Controls}

We controlled for transactional leadership because it builds upon already established transactional relations. Thus, it was necessary to control for contingent reward leadership to exclude the possibility that the effects could be attributed to the supervisor-intern relationship's transactional exchange nature. Four items measured the contingent reward leadership (e.g., "my direct supervisor points out what I will receive if I do what needs to be done") on a five-point scale, and the reliability was 0.72 . Additionally, we statistically controlled for prototypical and antiprototypical leadership behaviors using Epitropaki and Martin's (2004) implicit leadership theories scale, containing 21 prototypical (e.g., energetic) and antiprototypical (e.g., selfish) leader characteristics. Participants rated their supervisors on each trait with a five-point scale, from 1 (extremely uncharacteristic) to 5 (extremely characteristic).

\section{RESULTS}

To verify the discriminant validity of our measures, we conducted a series of confirmatory factor analyses. First, we estimated fit indices of two baseline measurement models: (1) a four-factor model for the antecedents (variables measured at $T_{1}$ ) and (2) a four-factor model for mediators and outcomes (variables measured at $\left.T_{2}\right)$. Results showed a good model fit for both models: (1) $\times 2(160)=260.3, p<0.001$; comparative fit index $(C F I)=0.94$; root mean square error of approximation $(R M S E A)=0.062$; and (2) $\times 2(129)=221.1, p<0.001 ; C F I=0.94 ;$ RMSEA = 0.066. Second, we contrasted these two models' fit against that of alternative models. Baseline models showed a significantly better fit than alternative measurement models did, thus confirming that our measures are adequate to capture the intended constructs.

Table 1 presents means, standard deviations, and correlations among the key constructs. Results indicate the relative lack of association between leader antiprototypical behavior and all models' constructs. Based on Becker's (2015) recommendations that inclusion of superfluous controls may yield biased estimates and reduce statistical power, we decided to exclude this variable from further analyses.

Our proposed model suggests an indirect effects model, whereby the relationship between leadership styles and behavioral outcomes is transmitted through satisfaction and stress. Table 2 summarizes the mediation models' regression coefficients.

Table 1. Means, standard deviations, correlations, and reliabilities

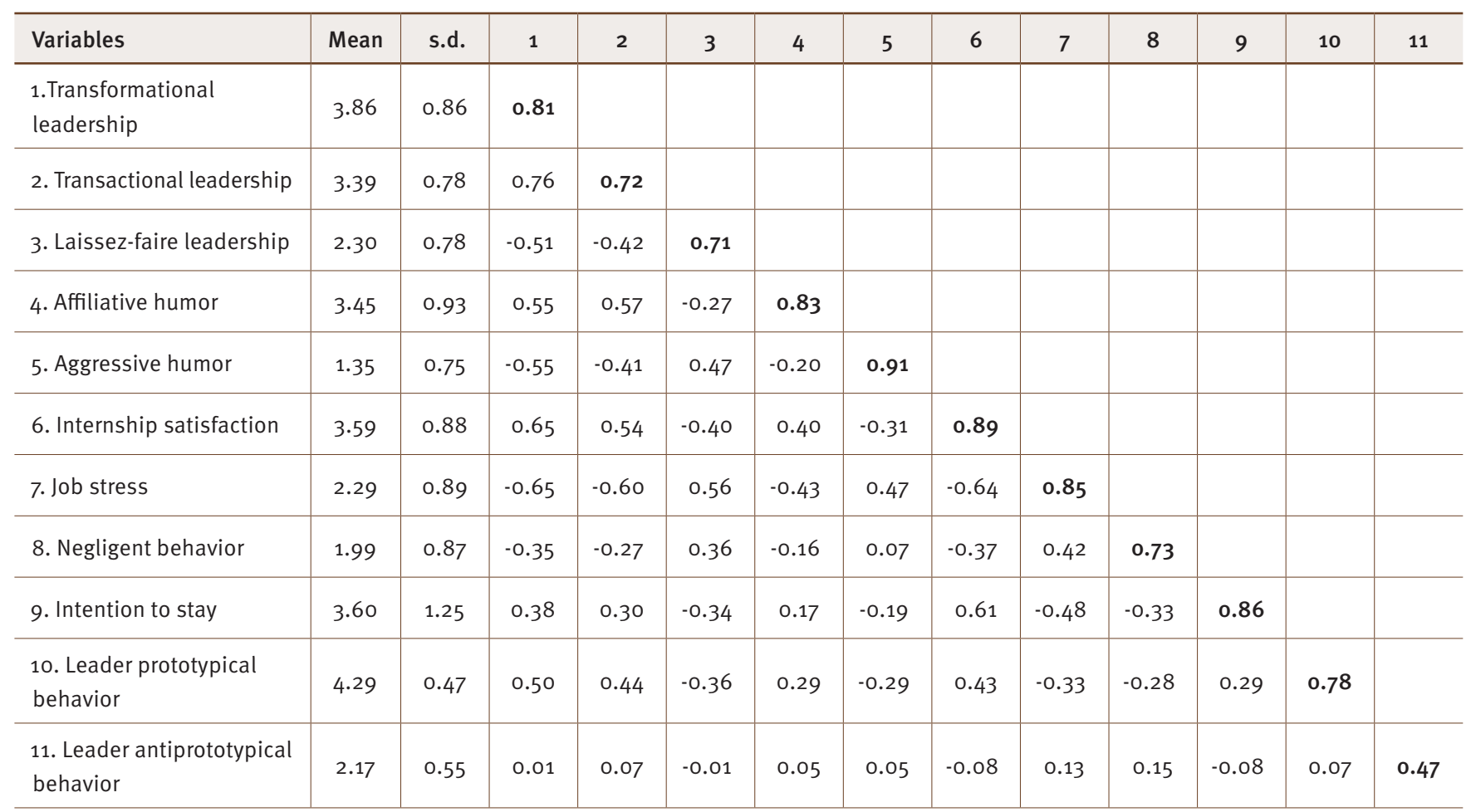

Note: $\mathrm{n}=164$

Alpha coefficients are in the diagonals. 
Table 2. Regression analyses for mediation models

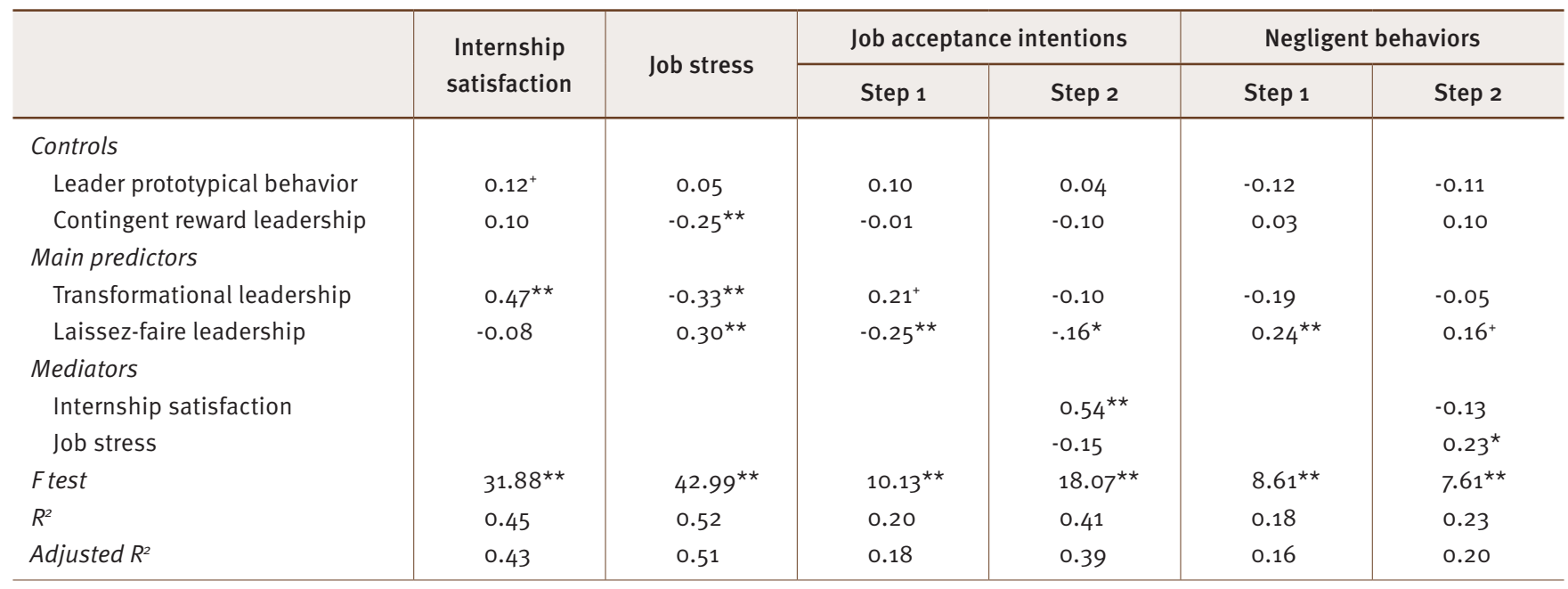

Note: $\mathrm{n}=164$ participants

p< $0.01 ;$ * $p<0.05 ;+p<0.10$

All coefficients are standardized and numbers are rounded to two decimal places.

Results show that transformational leadership is positively associated with internship satisfaction $(b=0.47, p<0.01)$ and negatively with stress $(b=-0.33, p<0.01)$, while laissez-faire leadership is positively associated with stress $(b=0.30, p<$ $0.01)$ but not with satisfaction $(b=-0.08, p>0.10)$. Moreover, satisfaction is positively and significantly related to job acceptance intentions $(b=0.54, p<0.01)$ but not with negligent behaviors at work $(b=-0.15, p>0.10)$. Contrariwise, a significant link was found between stress and negligent behaviors during the internship $(b=0.23, p<0.05)$, but not between stress and job acceptance intentions $(b=-0.13, p>0.10)$.

Concerning $\mathrm{H}_{1} \mathrm{a}$ and $\mathrm{H}_{2} \mathrm{a}$, we predicted that supervisors' use of affiliative humor moderates the relationship between leadership style and interns' satisfaction. Consistent with $\mathrm{H} 2 \mathrm{a}$, we found a negative interaction of affiliative humor by laissez-faire leadership $(b=-0.13, p<0.05)$. We then plotted simple slopes at one standard deviation above and below the moderator's mean to better understand this interaction effect (Graph 1). Consistent with our expectations, and supporting $\mathrm{H}_{2} \mathrm{a}$, the slope was relatively strong (and negative) for high affiliative humor (simple slope $=$ $-0.26, p<0.05$ ) but non-significant for low affiliative humor (simple slope $=0.00, p>0.10$ ). Considering the non-significant effect of laissez-faire leadership behavior and interns' satisfaction, this finding suggests that supervisors' use of affiliative humor not only enhances (as predicted) but may also activate laissez-faire leadership's negative impact on internship satisfaction.

\section{Graph 1. Internship satisfaction predicted by laissez-faire leadership moderated by affiliative humor}

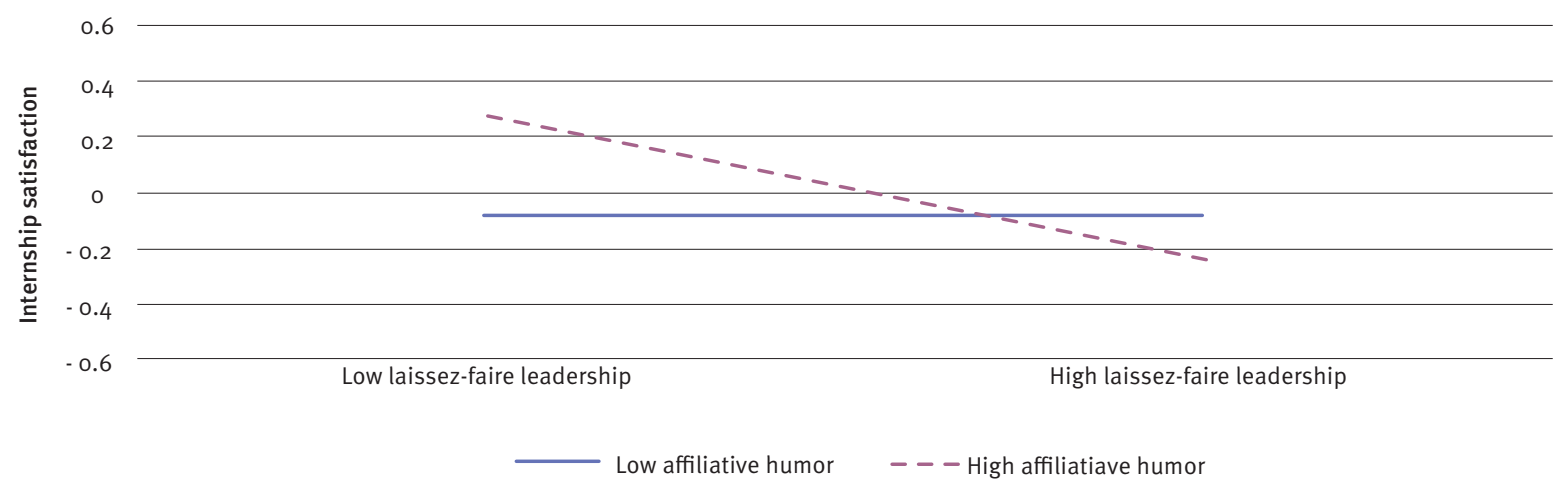

Note: Slopes at one standard deviation above the mean and one standard deviation below the mean. 
However, the interaction between affiliative humor and transformational leadership on satisfaction yielded a non-significant relationship ( $b=0.08, p>0.10$ ), meaning that using constructive humor does not enhance the effect of transformational leadership, providing no support for $\mathrm{H}_{1}$. That is, leaders' behavioral consistency does not have cumulative effects on interns' satisfaction.

Regarding aggressive humor's moderating role, $\mathrm{H}_{1} \mathrm{~b}$ and $\mathrm{H}_{2} \mathrm{~b}$ predicted that use of offensive humor interacts with supervisor leadership style, neutralizing the stress reduction effects of transformational leadership behaviors and enhancing the positive effect of laissez-faire leadership on stress. Results confirmed that the interaction between aggressive humor and transformational leadership on interns' stress is positive and significant $(b=0.10, p<0.05)$, supporting $\mathrm{H}_{1} b$ that aggressive humor attenuates the effect of transformational leadership behaviors on stress. By plotting this moderation effect (Graph 2), we conclude that the relationship between transformational leadership and stress is non-significant for high aggressive humor (simple slope $=-0.16, p>0.10$ ), whereas the slope is relatively strong (and negative) for low aggressive humor (simple slope $=-0.37, p<0.01)$. This finding suggests that if supervisors use offensive humor in their communication, transformational leadership behaviors do not reduce stress, whereas if they do not use sarcasm or mockery in their communication, it significantly impacts stress reduction.

\section{Graph 2. Stress predicted by transformational leadership moderated by aggressive humor}

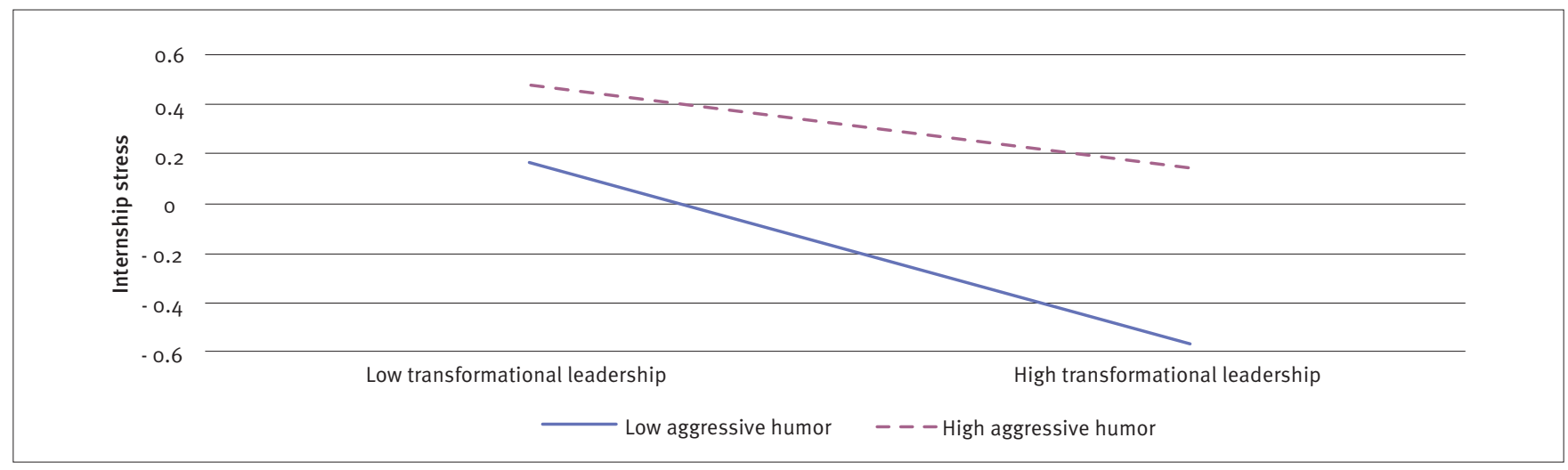

Note: Slopes at one standard deviation above the mean and one standard deviation below the mean.

Results also show the negative interaction of aggressive humor by laissez-faire leadership $(b=-0.13, p<0.05)$, which is corroborated by the relationship slopes between laissez-faire leadership and stress for high (simple slope $=0.12, p>0.10)$ and low $($ simple slope $=$ 0.39, $p$ < 0.01) aggressive humor, as shown in Graph 3. Contrary to our prediction, this finding suggests that supervisors' use of aggressive humor may neutralize, and not amplify as predicted, the negative impact of laissez-faire leadership on interns' stress.

\section{Graph 3. Stress predicted by laissez-faire leadership moderated by aggressive humor}

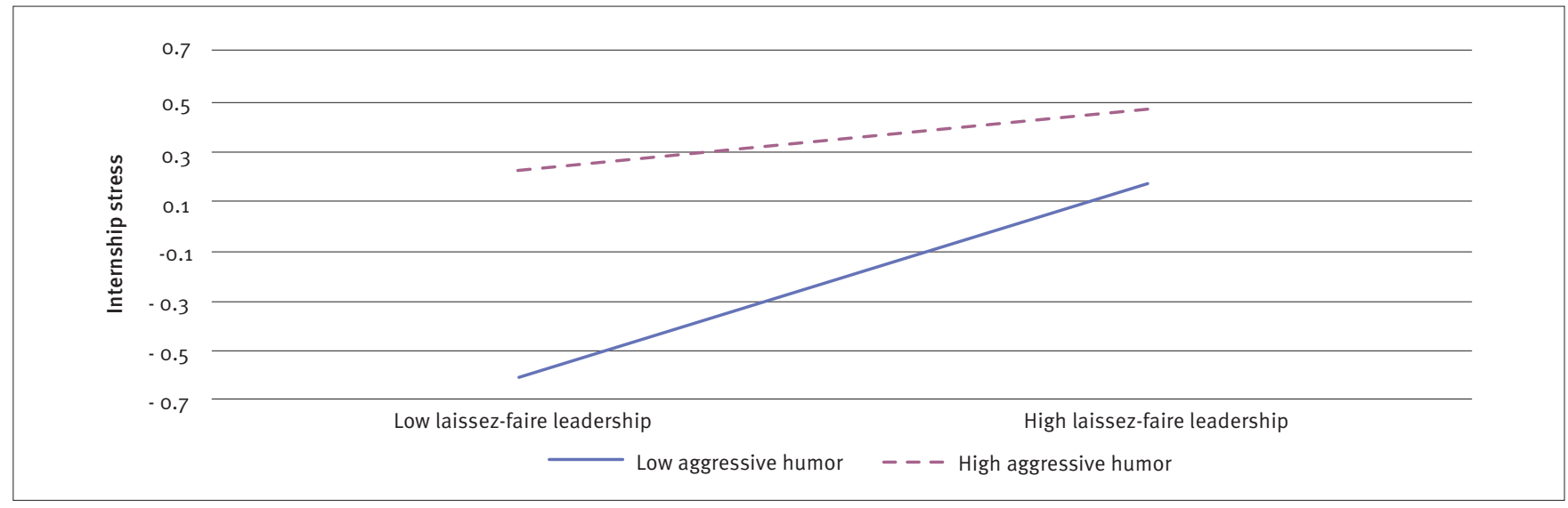

Note: Slopes at one standard deviation above the mean and one standard deviation below the mean. 
Furthermore, we predicted that supervisors' humor (affiliative and aggressive) moderates (indirectly, through stress and satisfaction) the impact of leadership styles on interns' behaviors (negligence and job acceptance intentions) -this has been termed the conditional indirect effect or moderated mediation (Preacher, Rucker, \& Hayes, 2007). To test such effects' significance, we used the recommended bootstrapping procedures to analyze the conditional indirect effects on outcome variables at different values of the moderator variable. Specifically, we examined the conditional indirect effect of contingent reward and laissez-faire leadership on job acceptance intentions (through satisfaction) at different values of affiliative humor. We also examined the conditional effect of transformational and laissez-faire leadership on negligent behaviors (through stress) at different values of aggressive humor.

Results (Table 3) show that the indirect effect of laissezfaire leadership on the intention to stay, mediated through satisfaction, was only significantly different from zero for affiliative humor values at one standard deviation above the mean $(b=-0.15 ; 95 \%$ bootstrap confidence interval $[\mathrm{Cl}]=-0.277$ to -0.059). Moreover, the transformational leadership's indirect effect on negligent behaviors (through stress) was statistically non-significant only for high aggressive humor at one standard deviation above the mean $(b=-0.05 ; 95 \%$ bootstrap $\mathrm{Cl}=-0.145$ to 0.004). This suggests that transformational leadership's negligence-reducing effects are annulled when supervisors use aggressive humor, although no evidence was found that affiliative humor increases transformational leadership effects. Similarly, the indirect effect of laissez-faire leadership on interns' negligent behaviors was found to be positive for low and moderate use of aggressive humor $(b=0.11$ and $b=0.07$, respectively), but not for high use of aggressive humor ( $b=$ $0.04 ; 95 \%$ bootstrap $\mathrm{Cl}=-0.012$ to 0.118 ). This finding suggests that while laissez-faire leadership generally impacts negligent behaviors at work, this effect is mitigated when coupled with aggressive humor.

\section{Table 3. Bootstrapped estimates of conditional indirect effects}

\begin{tabular}{|c|c|c|c|c|c|c|c|c|}
\hline Predictor & Mediator & Outcome & & ator & Effect & SE & LL $95 \%$ & UL $95 \%$ \\
\hline \multirow[b]{2}{*}{$\begin{array}{c}\text { Laissez-faire } \\
\text { leadership }\end{array}$} & \multirow[b]{2}{*}{ Internship satisfaction } & \multirow[b]{2}{*}{$\begin{array}{l}\text { Job acceptance } \\
\text { intentions }\end{array}$} & \multirow{2}{*}{ 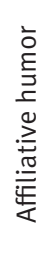 } & $-1 \mathrm{SD}$ & 0.00 & 0.06 & -0.135 & 0.117 \\
\hline & & & & M & -0.08 & 0.04 & -0.171 & 0.002 \\
\hline \multirow[b]{2}{*}{$\begin{array}{c}\text { Transformational } \\
\text { leadership }\end{array}$} & \multirow[b]{2}{*}{ Job stress } & \multirow[b]{2}{*}{ Negligent behaviors } & \multirow{2}{*}{ 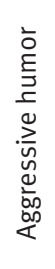 } & -1 SD & -0.11 & 0.06 & -0.267 & -0.033 \\
\hline & & & & M & -0.08 & 0.04 & -0.203 & -0.023 \\
\hline \multirow{3}{*}{$\begin{array}{l}\text { Laissez-faire } \\
\text { leadership }\end{array}$} & \multirow{3}{*}{ Job stress } & \multirow{3}{*}{ Negligent behaviors } & \multirow{3}{*}{ 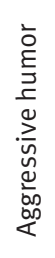 } & -1 SD & 0.11 & 0.05 & 0.034 & 0.248 \\
\hline & & & & M & 0.07 & 0.03 & 0.024 & 0.162 \\
\hline & & & & $+1 \mathrm{SD}$ & 0.04 & 0.03 & -0.012 & 0.118 \\
\hline
\end{tabular}

Note: $\mathrm{n}=164$ participants

All coefficients are standardized and numbers are rounded to two decimal places.

1,000 bootstrap samples

$-1 \mathrm{SD} /+1 \mathrm{SD}=$ one standard deviation below the mean / one standard deviation above the mean

$M=$ Mean

$\mathrm{LL}=$ lower limit confidence interval

$\mathrm{UL}=$ upper limit confidence interval 


\section{DISCUSSION}

The present study explored the effect of supervisors' behavioral (in)consistency on internship effectiveness. Overall, our study shows that inconsistency across leadership behaviors (e.g., transformational leadership and aggressive humor) is detrimental to internship outcomes. Our findings provide support for the argument that the simultaneous experience of two contradictory behaviors from supervisors that signal both approach and avoidance will trigger negative experiences and negative behavioral reactions (Ashforth et al., 2014). Although past studies provide evidence that supervisors' leadership styles are positively associated with internship outcomes (e.g., Newman, Rose, \& Teo, 2016), such relationships may be more complex than expected.

Accordingly, our findings suggest that while affiliative humor does not affect transformational leadership relationships (consistent behaviors), its negative impact on stress is neutralized when supervisors use aggressive humor (inconsistent behaviors). Further, use of affiliative humor may aggravate avoidance behaviors associated with the laissez-faire style. Interns may judge the use of humor (although positive) as abusive and inconsistent with their leaders' behaviors (i.e., instead of the needed guidance, they receive only empty jokes). This aggravating effect does not occur with aggressive humor, as the effect of laissez-faire leadership on interns' stress is neutralized by the use of negative humor.

Consistent with our results, past research also provides evidence that inconsistent behaviors have larger damaging effects than consistent ones (e.g., Nahum-Shani, Henderson, Lim, \& Vinokur, 2014). One possibility for this asymmetry may involve the feeling of ambivalence that could emerge when interns perceive inconsistency in supervisory behaviors (Ashforth et al., 2014). Such inconsistency, which signals opposite orientations to interns leads to experience of disorientation that characterizes ambivalence (e.g., transformational leaders who use aggressive humor signal to interns that they are simultaneously cared for and disregarded). When made salient, ambivalence gives rise to psychological discomfort and negative responses toward the target of ambivalence (Ashforth et al., 2014; Rothman et al., 2017). However, when supervisors behave in a consistent manner, they can prevent the emergence of ambivalence and the negative responses to it (Ashforth et al., 2014).

In sum, our results evidence that when a supervisor makes a consistent combination of leadership behaviors and use of humor, it ensures that the outcomes stemming from leadership behaviors are positive and fruitful, but when humor is not perceived as consistent for a certain leadership style, it impairs interns' attitudes and outcomes. We thus contribute to the leadership literature by revealing that supervisors' (in) consistency is especially relevant for the development of interns' work attitudes, behaviors, and intentions to be permanently hired by the host company. Overall, our findings contribute by showing that leadership styles affect intern outcomes, but often do so through indirect and contingent pathways that may obscure direct effects. In addition, our findings reinforce our central message that the interplay of leadership and humor styles is of key interest in understanding interns' behavioral reactions.

\section{MANAGERIAL IMPLICATIONS}

Our findings have some practical implications that need to be highlighted. First, our study contributes to the design and management of internship programs by stressing the role of leadership practices. If organizations want to leverage internships as a screening tool for recruitment purposes, they need to be aware of how managerial behaviors can impact interns' attitudes and intentions toward the host company.

Further, our results can help leaders understand that, while humor is a powerful workplace technique to lead interns, all humor forms are not similar. Leaders should emphasize the right form of humor in their communication with interns. Particularly, supervisors should be especially diligent in seeking consistency between communication styles and leadership behaviors.

\section{LIMITATIONS AND FUTURE RESEARCH}

Some limitations to this study must be acknowledged. Methodologically, we took multiple precautions around the single-source data (Podsakoff, MacKenzie, \& Podsakoff, 2012). Besides the two-wave design to reduce the likelihood of common method bias, we controlled for prototypical leadership behavior to exclude the chance that the differential effects of leadership styles could be attributed solely to supervisors' prototypical characteristics. Moreover, since the focus of our study was interaction effects and not direct effects, this common method concern is less problematic. In fact, the presence of common methods bias is shown to reduce interaction estimates, leading to more conservative effects (Siemsen, Roth, \& Oliveira, 2010). 
Second, our sample came from a relatively upper-class private school population in Brazil, a country known for wide economic disparity. On one hand, because Latin American samples are relatively rare in the organizational literature, our study represents an understudied group, thus contributing to undoing geographical biases in research; on the other hand, our sample is not representative of majority of Brazilians, who may face very different workplace challenges. Future research should thus look at interns from across the socio-economic spectrum.

Finally, our study relies on a broad and general theory of humor for explaining its effects on interns' attitudes and behaviors. However, we acknowledge the role of the cultural context in defining nationally or regionally distinctive styles of humor. In this sense, as Osland, De Franco, and Osland (2007) highlight, Latin American work settings are marked by a specific sense of humor and fun. Consequently, future investigations should take an indigenous approach to study humor in the Brazilian context.

Despite these limitations, the current research suggests that the use of humor interacts in complex ways with leadership styles, producing a range of moderating effects. Ultimately, these effects result in relevant employee outcomes that are important for organizations' success. Particularly, in Brazil, where studies bridging these two streams of research are lacking, our study highlights the importance of the relationship between humor and leadership, and it deserves further attention in future research.

\section{REFERENCES}

Adelswärd, V., \& Oberg, B. M. (1998). The function of laughter and joking in negotiating activities. Humor, 11(4), 411-429. doi:10.1515/ humr.1998.11.4.411

Arendt, L. A. (2009). Transformational leadership and follower creativity: The moderating effect of leader humor. Review of Business Research, 9(4), 100-106.

Ashforth, B. E., Rogers, K. M., Pratt, M. G., \& Pradies, C. (2014). Ambivalence in organizations: A multilevel approach. Organization Science, 25(5), 1453-1478. doi:10.1287/orsc.2014.0909

Avolio, B. J., Howell, J. M., \& Sosik, J. J. (1999). A funny thing happened on the way to the bottom line: Humor as a moderator of leadership style effects. Academy of Management Journal, 42(2), 219-227. doi:10.2307/257094

Baranik, L. E., Roling, E. A., \& Eby, L. T. (2010). Why does mentoring work? The role of perceived organizational support. Journal of Vocational Behavior, 76(3), 366-373. doi:10.1016/j.jvb.2009.07.004
Bass, B. M. (1985). Leadership and performance beyond expectations. New York, NY: The Free Press.

Bass, B. M., \& Avolio, B. J. (1990). Transformational leadership development: Manual for the Multifactor Leadership Questionnaire. Palo Alto, CA: Consulting Psychologists Press.

Becker, T. E. (2005). Potential problems in the statistical control of variables in organizational research: A qualitative analysis with recommendations. Organizational Research Methods, 8(3), 274-289.

Beenen, G. (2014). The effects of goal orientations and supervisor concerns on MBA intern learning and performance. Academy of Management Learning and Education, 13(1), 82-101. doi:10.5465/ amle.2012.0006

Beenen, G., \& Rousseau, D. (2010). Getting the most from MBA internships: Promoting intern learning and job acceptance. Human Resource Management, 49(1), 3-22. doi:10.1002/hrm.20331

Brayfield, A. H., \& Rothe, H. F. (1951). An index of job satisfaction. Journal of Applied Psychology, 35(5), 307-311. doi:10.1037/hoo55617

Clouse, R. W., \& Spurgeon, K. L. (1995). Corporate analysis of humor. Psychology: A Journal of Human Behavior, 32(3-4), 1-24.

Cooper, C. D. (2005). Just joking around? Employee humor expression as an ingratiatory behavior. Academy of Management Review, 30(4), 765-776. doi:10.2307/20159167

Cooper, C. (2008). Elucidating the bonds of workplace humor: A relational process model. Human Relations, 61(8), 1087-1115. doi:10.1177/0018726708094861

Cooper, C., Kong, D. T., \& Crossley, C. (2018). Leader humor as an interpersonal resource: Integrating three theoretical perspectives. Academy of Management Journal, 61(2), 769-796. doi:10.5465/ amj.2014.0358

D’Abate, C. P., Youndt, M. A., \& Wenzel, K. E. (2009). Making the most of an internship: An empirical study of internship satisfaction. Academy of Management Learning \& Education, 8(4), 527-539.

De Cremer, D. (2003). Why inconsistent leadership is regarded as procedurally unfair: The importance of social self-esteem concerns. European Journal of Social Psychology, 33(4), 535-550. doi:10.1002/ejsp.162

Duncan, W. J., Smeltzer, L. R., \& Leap, T. L. (1990). Humor and work: Applications of joking behavior to management. Journal of Management, 16(2), 255-278. doi:10.1177/014920639001600203

Epitropaki, O., \& Martin, R. (2004). Implicit leadership theories in applied settings: Factor structure, generalizability, and stability over time. Journal of Applied Psychology, 89(2), 293-310. doi:10.1037/00219010.89 .2 .293 
Fleming, P., \& Spicer, A. (2002). Workers' playtime? Unravelling the paradox of covert resistance in organizations. In S. R. Clegg (Ed.), Management and organization paradoxes (pp. 65-86). Amsterdam: Benjamins.

George, A. T. (2013). Leadership lessons from the Royal Navy. McKinsey Quarterly, 1, 121-126. Retrieved from https://www.mckinsey.com

Greatbatch, D., \& Clark, T. (2003). Displaying group cohesiveness: Humour and laughter in the public lectures of management gurus. $\mathrm{Hu}$ man Relations, 56(12), 1515-1544. doi:10.1177/00187267035612004

Gruner, C. R. (1999). The game of humor: A comprehensive theory of why we laugh. New York, NY: Transaction.

Hatch. M. J. (1997). Irony and the social construction of contradiction in the humor of a management team. Organization Science, 8(3), 275288.

Heiss, S. N., \& Carmack, H. J. (2012). Knock, knock; who's there? Making sense of organizational entrance through humor. Management Communication Quarterly, 26(1), 106-132. doi:10.1177/0893318911414914

Huang, K. P., \& Kuo, W. C. (2011). Does humor matter? From organizational management perspective. Journal of Social Sciences, 7(2), 141-145. doi:10.3844/jssp.2011.141.145

Hughes, L. W. (2009). Leader levity: The effects of a leader's humor delivery on followers' positive emotions and creative performance. Journal of Behavioral \& Applied Management, 10(3), 415-432.

Huo, W., Lam, W., \& Chen, Z. (2012). Am I the only one this supervisor is laughing at? Effects of aggressive humor on employee strain and addictive behaviors. Personnel Psychology, 65(4), 859-885. doi:10.1111/peps.12004

Ivancevich, J. M., \& Matteson, M. T. (1980). Stress and work: A managerial perspective. In J. C. Quick, R. S. Bhagat, J. E. Dalton, \& J. D. Quick (Eds.), Work stress: Health care systems in the workplace. (pp. 27-49). New York, NY: Praeger.

Judge, T. A., \& Piccolo, R. F. (2004). Transformational and transactional leadership: A meta-analytic test of their relative validity. Journal of Applied Psychology, 89(5), 755-768. doi:10.1037/0021-9010.89.5.755

Kark, R., Shamir, B., \& Chen, G. (2003). The two faces of transformational leadership: Empowerment and dependency. Journal of Applied Psychology, 88(2), 246-255. doi:10.1037/0021-9010.88.2.246

Kenny, M. E., Medvide, M. B., Minor, K. A., Walsh-Blair, L. Y., Bempechat, J., Ruane Seltzer, J. M., \& Blustein, D. L. (2015). A qualitative inquiry of the roles, responsibilities, and relationships within work-based learning supervision. Journal of Career Development, 42(2), 117-132. doi:10.1177/0894845314543496
Kim, T., Lee, D., \& Wong, N. Y. (2016). Supervisor humor and employee outcomes: The role of social distance and affective trust in supervisor. Journal of Business and Psychology, 31(1), 125-139. doi:10.1007/ s10869-015-9406-9

Leck, J. D., \& Saunders, D. M. (1992). Hirschman's loyalty: Attitude or behavior? Employee Responsibilities and Rights Journal, 5(3), 219230. doi:10.1007/BF01385049

Liu, Y., Ferris, G. R., Xu, J., Weitz, B. A., \& Perrewé, P. L. (2014). When ingratiation backfires: The role of political skill in the ingratiationinternship performance relationship. Academy of Management Learning \& Education, 13(4), 569-586. doi:10.5465/amle.2012.0399

Liu, Y., Xu, J., \& Weitz, B. A. (2011). The role of emotional expression and mentoring in internship learning. Academy of Management Learning \& Education, 10(1), 94-110. doi:10.5465/amle.10.1.zqr94

Lynch, O. H. (2002). Humorous communication: Finding a place for humor in communication research. Communication Theory, 12(4), 423-445. doi:10.1111/j.1468-2885.2002.tboo277.x

Lynch, O. H. (2009). Kitchen antics: The importance of humor and maintaining professionalism at work. Journal of Applied Communication Research, 37(4), 444-464. doi:10.1080/00909880903233143

Martin, R. A., Puhlik-Doris, P., Larsen, G., Gray, J., \& Weir, K. (2003). Individual differences in uses of humor and their relation to psychological well-being: Development of the humor styles questionnaire. Journal of Research in Personality, 37(1), 48-75. doi:10.1016/S0092-6566(02)00534-2

McHugh, P. P. (2017). The impact of compensation, supervision and work design on internship efficacy: Implications for educators, employers and prospective interns. Journal of Education \& Work, 30(4), 367-382.

Methot, J., Melwani, S., \& Rothman, N. B. (2017). The space between us: A social-functional emotions view of ambivalent and indifferent workplace relationships. Journal of Management, 43(6), 1789-1819. doi:10.1177/0149206316685853

Mullen, J., Kelloway, E. K., \& Teed, M. (2011). Inconsistent style of leadership as a predictor of safety behaviour. Work \& Stress, 25(1), 41-54. doi:10.1080/02678373.2011.569200

Nahum-Shani, I., Henderson, M., Lim, S., \& Vinokur, A. (2014). Supervisor support: Does supervisor support buffer or exarcebate the adverse effects of supervisor undermining? Journal of Applied Psychology, 99(3), 484-503. doi:10.1037/a0035313

Newman, A., Rose, P. S., \& Teo, S. T. (2016). The role of participative leadership and trust-based mechanisms in eliciting intern performance: Evidence from China. Human Resource Management, 55(1), 53-67. doi:10.1002/hrm.21660

Ng, T. W. (2017). Transformational leadership and performance outcomes: Analyses of multiple mediation pathways. Leadership Quarterly, 28(3), 385-417. doi:10.1016/j.leaqua.2016.11.008 
Osland, J. S., De Franco, S., Osland, A., (2007). Organizational implications of Latin American culture: Lessons for the expatriate manager. Economia e Gestão, 7(14), 109-120.

Podsakoff, P. M., MacKenzie, S. B., \& Podsakoff, N. P. (2012). Sources of method bias in social science research and recommendations on how to control it. Annual Review of Psychology, 65, 539-569. doi:10.1146/annurev-psych-120710-100452

Preacher, K. J., Rucker, D. D., \& Hayes, A. F. (2007). Addressing moderated mediation hypotheses: Theory, methods, and prescriptions. Multivariate Behavioral Research, 42(1), 185-227. doi:10.1080/00273170701341316

Pundt, A. (2015). The relationship between humorous leadership and innovative behavior. Journal of Managerial Psychology, 30(8), 878893. doi:10.1108/JMP-03-2013-0082

Pundt, A., \& Herrmann, F. (2015). Affiliative and aggressive humour in leadership and their relationship to leader-member exchange. Journal of Occupational and Organizational Psychology, 88(1), 108 125. doi:10.1111/joop.12081

Pundt, A., \& Venz, L. (2017). Personal need for structure as a boundary condition for humor in leadership. Journal of Organizational Behavior, 38(1), 87-107. doi:10.1002/job.2112

Robert, C., Dunne, T. C., \& lun, J. (2016). The impact of leader humor on subordinate job satisfaction: The crucial role of leader-subordinate relationship quality. Group \& Organization Management, 41(3), 375406. doi:10.1177/1059601115598719

Robert, C., \& Wilbanks, J. E. (2012). The wheel model of humor: Humor events and affect in organizations. Human Relations, 65(9), 10711099. doi:10.1177/0018726711433133

Romero, E. J., \& Cruthirds, W. (2006). The use of humor in the workplace. Academy of Management Perspectives, 20(2), 58-69. doi:10.5465/ amp.2006.20591005

Romero, E., \& Pescosolido, A. (2008). Humor and group effectiveness. Human Relations, 61(3), 395-418. doi:10.1177/0018726708088999

Rose, P. S. (2017). The intern to employee career transition: An outsiders perception of insider status. Journal of Career Development, 45(6), 566-579. doi:10.1177/0894845317725192

Rose, P. S., Teo, S. T. T., \& Connell, J. (2014). Converting interns into regular employees: The role of intern-supervisor exchange. Journal of Vocational Behavior, 84(2), 153-163. doi:10.1016/j.jvb.2013.12.005

Rothman, N. B., Pratt, M. G., Rees, L., \& Vogus, T. J. (2017). Understanding the dual nature of ambivalence: Why and when ambivalence leads to good and bad outcomes. Academy of Management Annals, 11(1), 3372. doi:10.5465/annals.2014.0066
Sant'Anna, A. S., Campos, M. S., \& Lófti, S. (2012). Liderança: 0 que pensam executivos Brasileiros sobre o tema? RAM-Revista de Administração Mackenzie, 13(6), 48-76. doi:10.1590/S167869712012000600004

Siggelkow, N., \& Rivkin, J. W. (2005). Speed and search: Designing organizations for turbulence and complexity. Organization Science, 16(2), 101-122. doi:10.1287/orsc.1050.0116

Siemsen, E., Roth, A., \& Oliveira, P. (2010). Common method bias in regression models with linear, quadratic, and interaction effects. Organizational Research Methods, 13(3), 456-476. doi:10.1177/1094428109351241

Sobral, F., \& Islam, G. (2015). He who laughs best, leaves last: The influence of humor on the attitudes and behavior of interns. Academy of Management Learning \& Education, 14(4), 1-19. doi:10.5465/ amle.2013.0368

Sosik, J. J., \& Godshalk, V. M. (2000). Leadership styles, mentoring functions received, and job-related stress: A conceptual model and preliminary study. Journal of Organizational Behavior, 21(4), 365-390.doi:10.1002/(SICI)1099-1379(200006)21:4く365::AID JOB14'3.0.CO;2-H

Sturdy, A., \& Fineman, S. (2001). Struggles for the control of affect: Resistance as politics and emotion. In A. Sturdy, I. Grugulis, \& H. Willmott (Eds.), Customer service: Empowerment and entrapment. London, UK: Macmillan/Palgrave.

Tepper, B. J. (2000). Consequences of abusive supervision. Academy of Management Journal, 43(2), 178-190. doi:10.5465/1556375

Terrion, J. L., \& Ashforth, B. E. (2002). From "I" to "we": The role of putdown humor and identity in the development of a temporary group. Human Relations, 55(1), 55-88. doi:10.1177/0018726702055001606

Tremblay, M., \& Gibson, M. (2016). The role of humor in the relationship between transactional leadership behavior, perceived supervisor support, and citizenship behavior. Journal of Leadership \& Organizational Studies, 23(1), 39-54. doi:10.1177/1548051815613018

Uchino, B., Cawton, R., Smith, T., Light, K., McKenzie, J., Carlisle, M., ... Bowen, K. (2012). Social relationships and health: Is feeling positive, negative, or both (ambivalent) about social ties related to telomeres? Health Psychology, 31(6), 789-796. doi:10.1037/a0026836

Vecchio, R., Justin, J., \& Pearce, C. (2009). The influence of leader humor on relationships between leader behavior and follower outcomes. Journal of Managerial Issues, 21(2), 171-194.

Vullinghs, J. T., De Hoogh, A. H. B., Den Hartog, D. N, \& Boon, C. (2018). Ethical and passive leadership and their joint relationships with burnout via role clarity and role overload. Journal of Business Ethics. doi:10.1007/s10551-018-4084-y 
Watson, D., Clark, L. A., \& Tellegen, A. (1984). Cross-cultural convergence in the structure of mood: A Japanese replication and a comparison with U.S. findings. Journal of Personality and Social Psychology, 47(1), 127-144. doi:10.1037/0022-3514.47.1.127

Wendlandt, N. M., \& Rochlen, A. B. (2008). Addressing the college-to-work transition: Implications for university career counselors. Journal of Career Development, 35(2), 151-165. doi:10.1177/0894845308325646
Zepeda, A. V., Franco, D. A. H., \& Preciado, O. A. P. (2014). O humor na estratégia de persuasão durante as campanhas eleitorais. Revista Brasileira de Ciência Política, (13), 245-258. doi:10.1590/S010333522014000100010

Zhao, H., \& Liden, R. C. (2011). Internship: A recruitment and selection perspective. Journal of Applied Psychology, 96(1), 221-229. doi:10.1037/a0021295 